\title{
Financial innovations and bank performance in Kenya: Evidence from branchless banking models
}

\begin{tabular}{|c|c|}
\hline \multicolumn{2}{|c|}{$\begin{array}{l}\text { Authors: } \\
\text { Chimwemwe Chipeta }^{1} \text { (D) } \\
\text { Moses M. Muthinja }^{2,3} \text { (D) }\end{array}$} \\
\hline \multicolumn{2}{|c|}{$\begin{array}{l}\text { Affiliations: } \\
{ }^{1} \text { School of Economic and } \\
\text { Business Sciences, Faculty } \\
\text { of Commerce, Law and } \\
\text { Management, University } \\
\text { of the Witwatersrand, } \\
\text { South Africa }\end{array}$} \\
\hline \multicolumn{2}{|c|}{$\begin{array}{l}\text { ²Department of Finance, } \\
\text { Risk Management and } \\
\text { Banking, College of Economic } \\
\text { and Management Sciences, } \\
\text { University of South Africa, } \\
\text { South Africa }\end{array}$} \\
\hline \multicolumn{2}{|c|}{$\begin{array}{l}{ }^{3} \text { Department of Business, } \\
\text { Faculty of Business and } \\
\text { Communication Studies, } \\
\text { St Pauls University, Kenya }\end{array}$} \\
\hline \multicolumn{2}{|c|}{$\begin{array}{l}\text { Corresponding author: } \\
\text { Chimwemwe Chipeta, } \\
\text { chimwemwe.chipeta@wits. } \\
\text { ac.za }\end{array}$} \\
\hline \multicolumn{2}{|c|}{$\begin{array}{l}\text { Dates: } \\
\text { Received: } 25 \text { Oct. } 2017 \\
\text { Accepted: } 20 \text { Apr. } 2018 \\
\text { Published: } 03 \text { Oct. } 2018\end{array}$} \\
\hline \multicolumn{2}{|c|}{$\begin{array}{l}\text { How to cite this article: } \\
\text { Chipeta, C., Muthinja, M.M., } \\
2018 \text {, Financial innovations } \\
\text { and bank performance in } \\
\text { Kenya: Evidence from } \\
\text { branchless banking models', } \\
\text { South African Journal of } \\
\text { Economic and Management } \\
\text { Sciences 21(1), a1681. } \\
\text { https://doi.org/10.4102/ } \\
\text { sajems.v21i1.1681 }\end{array}$} \\
\hline \multicolumn{2}{|c|}{$\begin{array}{l}\text { Copyright: } \\
\text { (C) 2018. The Author } \\
\text { Licensee: AOSIS. This } \\
\text { is licensed under the } \\
\text { Creative Commons } \\
\text { Attribution License. }\end{array}$} \\
\hline \multirow[b]{2}{*}{ 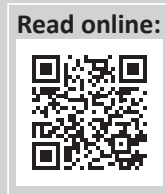 } & \\
\hline & $\begin{array}{l}\text { Scan this QR } \\
\text { code with your } \\
\text { smart phone or } \\
\text { mobile device } \\
\text { to read online. }\end{array}$ \\
\hline
\end{tabular}

Background: Kenya has become the epicentre of branchless banking financial innovations in the last decade, effectively attracting global research interest.

Aim: This article examines the relationship between financial innovation and the financial performance of 42 commercial banks in Kenya.

Setting: The financial innovations covered are the branchless banking models, which represent a departure from the traditional branch-based banking. More specifically, the financial innovations covered are: mobile banking, agency banking, internet banking and automated teller machines.

Methods: We use the Koyck dynamic distributed lag model to estimate the relationship between financial innovations and bank financial performance. The model has been using dynamic panel estimation with system generalised method of moments.

Results: The results show that financial innovations significantly contribute to bank financial performance, and that firm-specific factors are more important in determining the firm's current financial performance than industry factors.

Conclusion: We provide evidence that financial innovations generate good results for the shareholders, suggesting that shareholders are the primary beneficiaries of financial innovations used by commercial banks.

\section{Background and motivation}

Financial innovation is an area of economics that has attracted significant research interest in academia as well as in corporate circles (Lerner 2006; Lopez \& Roberts 2002). For instance, Laeven, Levine and Michalopoulos (2015) argue that new financial arrangements have historically emerged following the successful introduction of technological innovations. The financial arrangements include new financial instruments, the emergence of new financial institutions, or application of new reporting techniques (Laeven et al. 2015). These assertions are consistent with Frame and White's (2014) work, which observes that technological developments have significantly changed commercial banking business in the last 30 years. They argue that, in general, technological developments have contributed to the entrenchment of commercial banks in the network of global financial institutions undertaking a range of financial activities. In particular, Frame and White's (2014) study provides evidence that firstly, financial innovations have been catalysed by technological developments in the telecommunications sector, and secondly, financial innovations have altered not only bank products and services but also bank production processes. Evidently, the link between financial innovation and firm performance is complex, necessitating further research (Jiménez-Jiménez \& Sanz-Valle 2011). The degree of complexity is further compounded by a number of studies which have attempted to link innovation to either past or future firm performance. For instance, Bowen, Rostami and Steel (2010) argue that although there is a positive link between innovation and future performance, the link between innovation and past performance is unclear.

Notably, recent technological innovations have led to the emergence of new financial innovations worldwide. The implication of this development is that most of the studies in previous years, largely carried out in the developed world, have not kept pace with new financial innovations in developing countries. The dearth of research data on emerging financial innovations could partly be explained by the fact that the innovations, such as mobile money and agency banking, are not common in developed countries (Ingenico 2012). We examine the link between financial innovation in the form of branchless banking models and bank financial performance in Kenya's commercial banks. 
The new technological developments provide an imperative for carrying out the present study. For example, the emergence of new payment systems which mainly use mobile phones to transfer funds electronically (electronic money), has significantly altered banking services in Africa. The focus on Kenya is motivated by several factors. Firstly, The Central Bank of Kenya (CBK) (2015) shows that mobile payments in Kenya have overtaken all electronic card payments combined, in terms of the number of customers and the overall value of the payment transactions. In addition, mobile payment platforms are being employed in every aspect of human life. These aspects include utilising mobile phones to transfer money in deposit accounts held with commercial banks, withdrawing cash from bank accounts, payment of insurance premiums, payment of utility bills, air ticketing, retail outlets, and many more. The many uses of mobile financial innovations underline the importance of research in the field.

Importantly, the use of third parties to transact banking business, commonly referred to as agency banking, has grown substantially. This is in spite of the fact that it has been in operation in Kenya since 2012. The CBK (2015) reports indicate that $90 \%$ of agency banking in Kenya is controlled by three commercial banks and the individual financial reports of the three banks confirm on average that $30 \%$ of the total revenue is accounted for by agency banking. Agency banking outlets are located in rural areas, mostly in locations where it would be practically impossible or unprofitable for the commercial banks to establish fully-fledged branches.

Secondly, Kenya is a member of the east African community, comprising Burundi, Kenya, Rwanda, Tanzania and Uganda. East Africa is moving fast toward regional integration, with joint infrastructure projects being undertaken. The overall performance of the east African region will largely depend on developments taking place in Kenya (Kimenyi \& Kibe 2014). Lastly, the mobile money services sector in Kenya is the most advanced in the world (Cracknell 2012). The country has a robust mobile money agent network and adequate regulatory support from the CBK. In addition, DemirgüçKunt and Klapper (2012) observe that Kenya is sub-Saharan Africa's regional leader in mobile money. The study finds that $86 \%$ of all mobile phone users in Kenya use mobile money compared to $23 \%$ in the rest of sub-Saharan Africa. Therefore, Kenya is at the focal point of financial innovations in the world. This is supported by Cracknell's (2012) work, which classifies a Kenyan bank as Africa's most successful microfinance-focused bank, and a mobile phone service provider in Kenya as the world's leading provider of mobile payments. The Economist Intelligence Unit (EIU) Global microfinance survey ranks Kenya at position five globally, the highest ranking in Africa (EIU 2012). The study attributes Kenya's ranking to its global leadership and pioneering in mobile banking services. Moreover, recent studies document Kenya as the leader in terms of electronic payments, as well as bank branches and bank agents in Africa (EIU 2015).

The evolution of a number of branchless banking models has motivated research interest in Kenya's financial markets and a number of studies in the subject. However, most of the studies have focused on describing the existing financial innovations and the history pertaining to their introduction in Kenya (see Hughes \& Lonie 2007; Jepkorir 2010; Siedek 2008). All these studies have followed a consistent pattern of providing descriptive statistics on the financial innovations in Kenya, but fall short of empirical analysis. This lack of empirical rigour with regard to financial innovations is observed in other studies as well (Frame \& White 2004, 2014). Further to this, the link between financial innovations and firm performance in Kenya has been documented to some extent, by a few studies (see Makini 2010; Mwando 2013). However, none of the studies follow a holistic approach to the study of financial innovation and its impact on firm financial performance.

The studies discussed in the literature review have left knowledge gaps in the field of financial innovations, especially in Kenya, which the present article seeks to address. Firstly, failure or inability to assess empirically the value of financial innovations to innovating firms, has managerial implications in the sense that, in the absence of empirical evidence linking financial innovation to firm financial performance, there is no incentive to innovate. Secondly, studies which have attempted to link financial innovations to firm performance have created a bypass around empirical approaches, consistent with Frame and White's (2004) findings. The implication of this state is that most of the findings are largely anecdotal, owing to the (possible) subjective nature of the responses to questionnaires. The article addresses these research gaps by examining financial innovations in two industries namely banking and telecommunications. The financial innovations in the banking industry include bank-focused and bank-led models. Non-bank-led financial innovation models are found in the telecommunications industry.

The results show that financial innovations are associated with a significant positive impact on the performance of banks in Kenya. While controlling firm-specific and macroeconomic factors, the use of automated teller machines (ATMs), agency and mobile banking contribute significantly to the operating performance of banks in Kenya. These results further confirm the dominance of mobile banking over the two branchless banking models (ATMs and agency banking). The rest of the article is structured as follows: section two reviews the literature on financial innovation, section three describes the data and methodology, section four presents the results of the study and section five concludes and provides recommendations for future research.

\section{Literature review}

\section{Financial innovation}

Financial innovation is defined in broad terms as '... the act of creating and then popularising new financial instruments as well as new financial technologies, institutions and markets ...' (Tufano 2003:4). Tufano argues that innovations can be categorised into process and product innovations, where product innovations are denoted by new financial 
instruments, while process innovations are epitomised by innovative methods of distributing the financial products, dispensing transactions or pricing them. Tufano (2003) observes that although innovation fluctuates, with some periods exhibiting high levels of innovation and others low, in the long run financial innovation is a distinct part of a growing economy. These findings resonate well with the recent developments in a new generation of financial innovations in Kenya, namely branchless banking models. Whereas most financial innovation studies in developed countries have largely concentrated on financial products, the study of process innovations appears to have been given a wide berth, especially in developing countries. The emphasis of the present study is on the process innovations used in delivering financial products. The delivery of financial products through financial innovation should improve firm performance.

The multidimensional nature of firm performance and its multiple definitions make it more challenging to measure adequately. For instance, it is argued that:

\footnotetext{
'... the challenge of measuring companies relative performance across industries and eras, declaring the top performers and finding the common drivers of their success is so daunting that it might seem a fool's errand to attempt.' (Kirby 2005:30)
}

Assessing the performance of firms operating in multiple industries is even more complex due to the problem of allocating balance sheet and income statement items, such as sales and asset items, among the many industries within which they operate (Dess \& Robinson 1984). Dess and Robinson argue that: firstly, making accurate estimates through survey techniques is a difficult task which represents a major source of measurement error, secondly, the measurement errors emanate from the confidential nature of the data and the application of different accounting policies and procedures among firms and lastly, assessing firm performance in a single industry for privately held firms is even more difficult.

\section{Innovation and firm performance}

A number of studies have reviewed the relationship between firm financial performance and innovation in manufacturing as well as innovation in services. For instance, Rosenbusch, Brinckmann and Bausch's (2011) meta-analysis of previous research on the relationship between innovation and firm performance aims at establishing the direction and strength the relationship has on the performance of small and medium enterprises. They document a positive relationship between innovation and performance and that investment in process innovation leads to higher firm performance than investment in product innovations. However, the findings are largely equivocal as to what explains the variation in returns from investment in process and product innovations. According to Laforet (2013), few companies have empirically examined innovation outcomes at the firm level or the link between a firm's innovation and that firm's performance. On the other hand, Artz et al. (2010) studied 272 firms derived from
35 industries over 19 years to establish the firms' ability to generate benefits from their inventions and innovation as well as the effect of the innovation on firm financial performance. The study observed a negative relationship between patents and performance as measured by both return on assets (ROA) and sales growth. Nonetheless, the negative link between innovation and firm financial performance observed in Artz et al.'s work (2010) could be as a result of the use of an inappropriate proxy for innovation, namely patents. This is because patents may not necessarily result from innovation.

Jiménez-Jiménez and Sanz-Valle's (2011) work finds a positive relationship between innovation and firm performance. The authors argue that the strength of the relationship between innovation and firm performance is higher for bigger and older firms in the manufacturing sector. The respondents to the questionnaires used in the study were asked about the evolution of their firm's performance over the preceding 3 years. The findings of the study; however, may not be replicated in other studies in view of the subjective nature of the performance measures used. Recent studies observe a link between innovation and firm performance. For instance, Aduda and Kingoo's study (2012) of the relationship between electronic banking and financial performance of commercial banks in Kenya finds a strong positive relationship between bank performance and e-banking innovations. Using ROA as proxy for bank performance and the number of ATMs and debit cards as proxy for e-banking, Aduda and Kingoo (2012) find that innovation contributes to performance of large firms as well as small and medium enterprises. Additionally, Rosenbusch et al. (2011) argue that innovative products enable small- and medium-sized enterprises (SMEs) to compete with large and established firms. According to Rosenbusch et al. (2011), innovative products enable small firms to avoid price competition and also create new demands which contribute to the firm's growth.

DeYoung, Lang and Nolle's (2007) study of 424 community banks comprising the earliest adopters of internet banking in USA explains the implication of financial innovation adoption. The study compares the change in the banks' 1999 - 2001 financial performance with that of 5175 community banks using branch-only banking. They find an improvement in the profitability of the early adopters of internet banking among community banks associated with internet banking. In addition, Hernando and Nieto (2007) provide a quantitative analysis of the impact of internet banking and the financial performance of 72 banks in Spain. They find that the reduction in transaction costs leads to an expansion in the banks' profitability. Lastly, Cainelli, Evangelista and Savona (2006) assess the impact of innovation on the service firms' economic performance by both conceptually and empirically exploring the bi-relationship between innovation and firm-level economic performance in services. They attempt to establish the existence of a virtuous circle between innovation and firm-level economic performance and report several important findings. Firstly, the study finds a strong positive relationship between innovation and a firm's economic performance. 
Secondly, innovating firms perform better than noninnovating firms in terms of economic growth and productivity. Thirdly, a reverse or circular relationship between innovation and firm performance is evidenced by the higher propensity for better performing firms to innovate and commit their capital to innovation. The relationship between innovation and firm performance is therefore twoway, meaning there is a reverse causation between the two. Importantly, innovation enables small firms to become big enough to afford large expenditures in innovation and associated research and development. The findings indicate that firms with high turnover, as evidenced by high sales growth, show above-average innovation expenditure in information and communication technology, encompassing both hardware and software. These findings are consistent with the earlier work of Gopalakrishnan (2000) on the reverse causality between innovation and financial performance.

It appears from the literature that most of the studies on firm performance and innovation have been carried out in developed countries. However, critical success factors for innovation may not be replicable across geographical regions and markets due to cultural differences (Al-Ansari, Pervan \& Xu 2013; Laforet \& Tann 2006). Consequently, more studies are needed across geographical regions for purposes of comparison. The studies reviewed in the preceding sections provide evidence of the existence of a link between innovation and firm performance in different setups. From the reviewed studies, there is evidence linking innovation to firm financial performance for both small and large firms. Product and process innovation help the firms in improving performance as well as enabling small firms to compete with large firms. On the other hand, small firms use innovation to create niche markets for their new products and to avoid price competition with large firms. We seek to establish the link between the performance of Kenya's commercial banks and their usage of financial innovations. This is in view of the reviewed studies and the Kenya's banking sector performance over the period of study.

\section{Performance of Kenya's banking sector}

Kenya's banking sector has, over the 10-year study period, grown remarkably in terms of total assets, total deposits and other parameters. The sector performed well in spite of the post-election and global financial crisis shocks, as well as changes in political regimes over the period. The banking sector is largely concentrated in favour of six large banks, which take a lion's share of the banking sector performance. The CBK groups banks into 'peer groups' based on total assets, whereby banks are classified as 'large' if their total assets are above 15 billion Kenya Shillings (Ksh), 'medium' if their total assets are between Ksh 5 billion and Ksh 15 billion and as 'small' if total assets are less than Ksh 5 billion. Some banks have moved from lower classification to higher ones and vice versa over the study period. Although large banks account for a bigger share of the sector performance, the banking sector has generally been on upward trajectory in terms of growth, as illustrated in Figure 1.

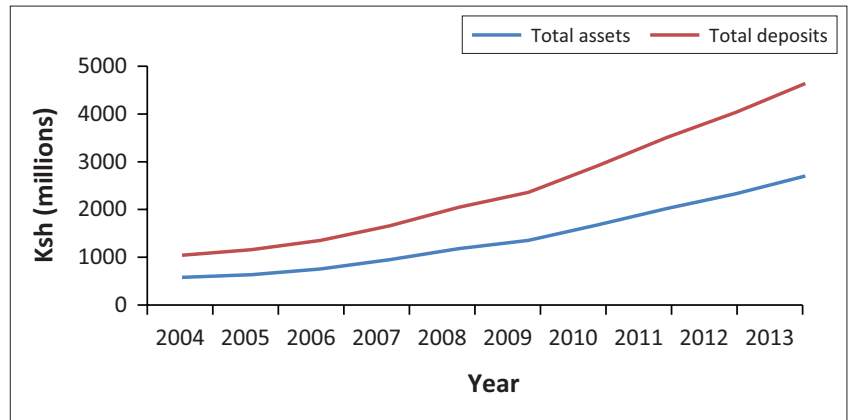

Ksh, Kenya Shillings.

FIGURE 1: Growth in total deposits and total assets.

The peer group classification led to over $50 \%$ of the banks being classified as 'large' in the year 2010, necessitating a revision of the grouping criteria (CBK 2010). The classification of banks into three peer groups since 2010 has been based on the weighted composite index, which comprises total assets, deposits, capital size, number of deposit accounts and loan accounts (CBK 2010). As at December 2013, six banks were classified as large, 15 as medium and 23 as small (CBK 2013). The six large banks account for $52.39 \%$ of the (weighted) market size, medium banks account for 37.95\% and the 23 small banks control a paltry $9.66 \%$ of the market. Consequently, these statistics provide evidence of high concentration in the banking sector, which is likely to reduce small banks to mere followers and imitators of the financial innovations developed by large banks. The dominance of large banks in terms of total assets and total deposits implies that large banks have sufficient resources to develop financial innovations. Figures 2 and 3 illustrate the performance of the peer groups since the year 2006, although the composition of the individual peer groups has varied over time. The apparent decline in total assets for all peer groups in year 2010 is as a result of the change in classification criteria for the peer groups.

\section{Data and methodology Data sources and variables}

This article uses secondary data obtained from a number of sources. The commercial banks' financial performance and banking industry performance data were obtained from CBK Bank supervision annual reports and from the respective banks financial reports downloaded from Bankscope ${ }^{1}$. Financial innovations data was largely obtained from individual company websites, financial reports, as well as media reports. The data on listed companies were obtained from Capital Markets Authority (Kenya), while Kenya's economic performance data were extracted from Kenya National Bureau of Statistics and the World Bank Development Indicators. The population of the study comprises all locally and foreign-owned commercial banks in Kenya which are not under statutory management. We use the data on the number of bank accounts for each bank contained in the CBK Annual Bank supervision reports as proxies for internet accounts. The data on the number of bank accounts are available for the period 2009-2013, that is, half of the period 1.Licensed to the University of the Witwatersrand, South Africa. 
studied. Over the period of study, the data collected from the individual commercial banks reports and websites, as well as media reports indicate that $90 \%$ of agency banking is controlled by three large banks. Although ATM data for the banking sector is available from the CBK reports, individual banks' ATMs were harder to get and, therefore, involved a

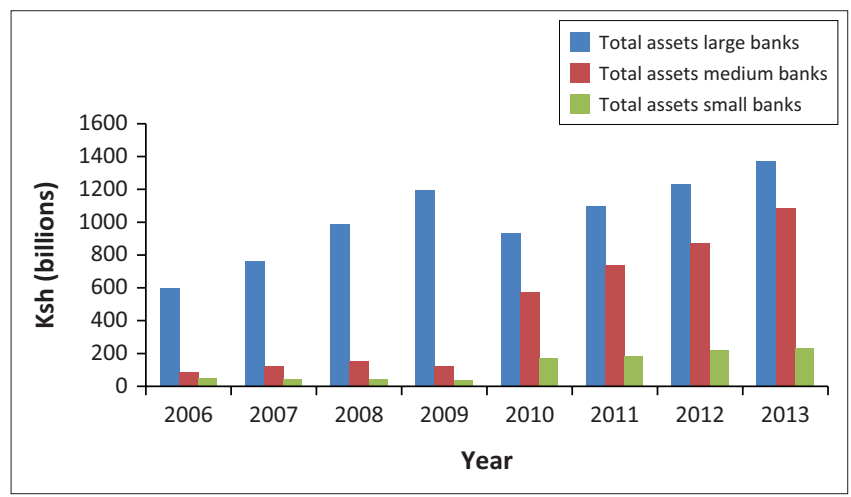

Ksh, Kenya Shillings.

FIGURE 2: Growth in peer groups' total assets.

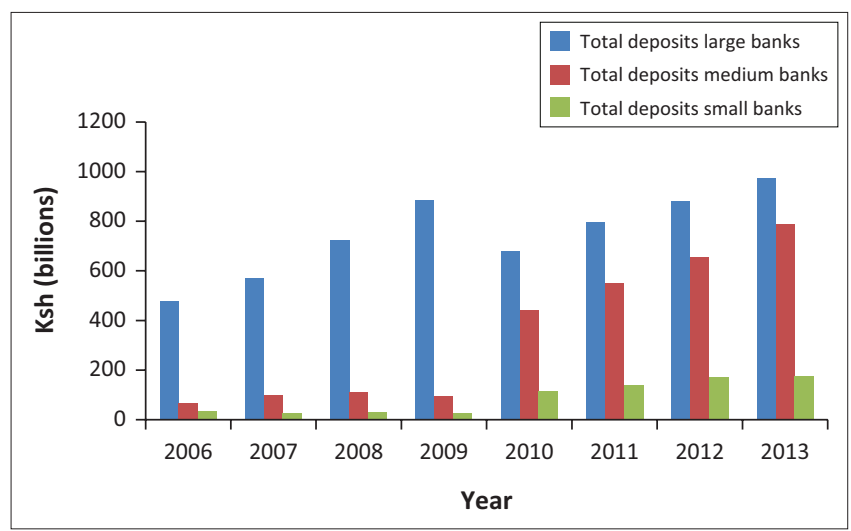

Ksh, Kenya Shillings.

FIGURE 3: Growth in peer group's total deposits. combination of multiple sources, such as annual reports and websites of individual banks and media reports. All the data on mobile payments were obtained from the CBK National payment statistics contained in the CBK website. Therefore, the challenges regarding the sources of the data lead to an unbalanced data panel. The structure of the data has informed our choice of systems - generalised method of moments (GMM), as discussed in section 3.3. The sample size comprises 42 out of the 43 commercial banks. One of the sampled commercial banks was excluded, as it was under statutory management during the study period. The variables used in this article are defined in Table 1.

\section{Model specification}

This article uses a dynamic distributed lag model to estimate the relationship between financial innovations and bank financial performance. This is because the lagged values of the dependent variable (firm performance) are included among the explanatory (financial innovation) variables (Gujarati 2003). The independent variables are also lagged since it takes time before the investment in financial innovations can have a significant impact on firm performance. A number of reasons would account for the lag in the financial innovation impact on firm performance. Firstly, according to Griliches (1967), the decision to invest in research and development (R\&D) expenditure and its ultimate payoff in terms of productivity involves not only considerable lag but also several different lags. Since investment in financial innovations usually involves considerable R\&D expenditure, it takes time before the investment in $R \& D$ as well as the capital cost of the information and communications technology infrastructure can be recouped.

Secondly, the adoption and use of electronic payments is prone to network externalities. A network effect or externality arises when the value of a product to one user depends on the

TABLE 1: Variable definition

\begin{tabular}{|c|c|c|}
\hline Variable & Category of variables & Definition \\
\hline IndAdjROA & $\begin{array}{l}\text { Operating performance } \\
\text { variables }\end{array}$ & $\begin{array}{l}\text { The industry-adjusted return on total assets for bank } i \text { at time } t \text {. It is arrived at by deducting the average industry ROA from the ROA } \\
\text { of the firm, then dividing the result by the standard deviation of in the industry ROA. }\end{array}$ \\
\hline IndAdjROE & & $\begin{array}{l}\text { The industry-adjusted return on equity for firm } i \text { at time } t \text {, and is calculated by subtracting the average industry ROE from the ROE } \\
\text { of the firm, and dividing the result by the standard deviation of in the industry ROE. }\end{array}$ \\
\hline ATM & $\begin{array}{l}\text { Financial innovation } \\
\text { variables }\end{array}$ & $\begin{array}{l}\text { Automated Teller Machines, and is defined as the number of ATMs for firm } i \text { at time } t \text {, divided by the total number of industry ATMs } \\
\text { at time } t \text {. }\end{array}$ \\
\hline IB & & $\begin{array}{l}\text { Internet Banking, defined as the number of firm } i \text { internet accounts at time } t \text {, divided by the total number of internet accounts in the } \\
\text { industry at time } t \text {. The number of internet accounts is represented by the number of deposit accounts. }\end{array}$ \\
\hline Lnmbtn & & The logarithm of number of mobile banking transactions for firm $i$ at time $t$. \\
\hline IndROA & Control variables & The average value of the industry return on total assets at time $t$. \\
\hline IndROE & & The average value of the industry return on equity at time $t$. \\
\hline LNTA & & The logarithm of total assets for firm $i$ at time $t$. \\
\hline Listing & & A dummy variable that captures the effects of listing on the NSE. A value of 1 is assigned to firms listed on the NSE, and 0 otherwise. \\
\hline ows & & A dummy variable that captures the ownership effects of sampled firms. A value of 1 is assigned to locally owned firms, and 0 otherwise. \\
\hline PG & & $\begin{array}{l}\text { The peer group of the banking firms. The banks are grouped into three peer groups that is, large, medium and small. The classification } \\
\text { of banks into three peer groups since } 2010 \text { has been based on the weighted composite index which comprises: total assets, deposits, } \\
\text { capital size, number of deposit accounts and loan accounts (CBK 2011). As at December } 2013 \text {, six banks were classified as large, } 15 \text { as } \\
\text { medium and } 23 \text { as small. The six large banks account for } 52.39 \% \text { of the (weighted) market size, medium banks account for } 37.95 \% \text { and } \\
\text { the } 23 \text { small banks control a paltry } 9.66 \% \text { of the market. }\end{array}$ \\
\hline
\end{tabular}

IndAdjROA, industry-adjusted return on assets; IndAdjROE, industry-adjusted return on equity; ATM, automated teller machine; ROE, return on equity; IB, Internet banking; AB, Agency banking; Lnmbtn, The logarithm of number of mobile banking transactions; IndROA industry return on assets; IndROE, industry return on equity; LNTA, The logarithm of total assets for firm $i$ at time $t$; NSE-Nairobi Securities Exchange; OWS, ownership; GDP, gross domestic product; PG, peer group; ROE, return on equity; ROA, return on assets. 
number of other users of the same product (Katz \& Shapiro 1986). According to Shapiro, Varian and Becker (1999), technologies prone to network effects have a tendency to show a long lead time followed by rapid growth. The authors argue that as existing customers return positive feedback, the customer base grows, thus making the adoption of the product worthwhile for many more users; eventually the product achieves a critical mass and takes over the market.

Thirdly, individuals are naturally resistant to change, especially culture change, because of the discomfort that change offers. In most cases, customers adopt a 'wait and see' attitude and therefore adopt the innovations at a later date. Such customers are referred to as 'laggards', possibly because of their lagged response to the introduction of new products and innovations. The resistance to change in favour of adoption and usage of financial innovations may also be attributed to risk factors, such as the fear of money laundering and the risk of fraud associated with the use of third parties to access personal accounts under agency banking.

In view of these observations, a general distributed lag model is expressed as follows:

$Y_{i, t}=\alpha_{i}+\beta_{0} X_{i, t-k}+\theta Z_{i, t}+\mu_{i, t}$

where $Y_{i, t}$ is the measure of firm performance (IndAdjROA, INDADROE).

When using a firm's ROE and/or ROA, it is possible to find unusually high or unusually low values for either of these ratios. However, the use of industry-adjusted ROE and ROA can mitigate this effect (Kayanga 2008). These measures give us an indication of relative performance. $X_{i, t-k}$ represents the lagged values of financial innovation variables ( $A T M, I B, A B$ and $L n m b t n) . Z_{i, t}$ represents control variables for firm $i$ at time $t_{r}{ }^{2}$ and $\mu_{i, t}$ is the error term. These variables are defined in Table 1. To estimate the distributed lag model, the Koyck (1954) transformation distributed lag model is used. This model is expressed as follows:

$Y_{i, t}=\alpha_{i}(1-\lambda)+\lambda Y_{i, t-1} \beta_{0} X_{i, t-k}+\theta Z_{i, t}+\mu_{i, t}$

Where, $Y_{i, t-1}$ represents lagged values of the independent variable. $\mu_{i, t}=\left(u_{t}-\lambda u_{t-1}\right)$ is a moving average of $u_{t}$ and $u_{t-1} \cdot u_{t}$ is time $t$ error term while $u_{t-1}$ is $t-1$ error term. The Koyck model has been used in recent financial innovation studies (Muthinja \& Chipeta 2017).

\section{Estimation technique}

This article adopts a dynamic model specification for a number of reasons. Firstly, past literature has observed that firm performance shows persistent effects, meaning that past performance affects present performance. Secondly, firm

2.The independent variables measure financial innovation usage and have been scaled down using industry usage of the financial innovations. Frambach and scaled dow (2002) industry usage Schillewaert (2002) contend that the innovation process becomes successful upon its acceptance and integration into the organisation and the demonstration of commitment through continued use of the product innovation. According to Rogers (1995), this commitment entails the decision to make full use of an innovation as the only best available course of action. performance is not only influenced by the present financial innovation but also past financial innovations. Formally, the model is specified as shown in Equation 1. A priori, the optimal lag in Equation 1 is unknown. However, if we assume that the effect of past financial innovation decays gradually (over time) to zero, as argued by Koyck (1954), then Equation 1 can transform using Koyck transformation. The resulting equation through the transformation process leads to Equation 2. Estimating Equation 2 using ordinary least squares, fixed or random effect models gives rise to a number of econometric issues such as autocorrelation and heteroscedasticity. However, the dynamic GMM developed by Arellano and Bond (1991) helps address these challenges. In addition, the model has been found to be robust to measurement errors, addresses some endogeneity and is well suitable where we have small $t$ and large $n$. Given the structure of the panel data of this study, where $t=10$ and $n=42$, dynamic GMM is, therefore, the most suitable estimation technique. The dynamic Koyck distributed lag model is, therefore, estimated using GMM (Arellano \& Bond 1991; Arellano \& Bover 1995; Blundell \& Bond 1998).

The GMM models are ideal for analysing and estimating data with small time periods, data which is replete with measurement errors and for models whose independent variables are likely to be endogenous. Consequently, the implication from these studies is that dynamic panel estimation technique is the most appropriate for the present study for a number of reasons. Firstly, the presence of lagged dependent variable, $Y_{i, t}$ in our model leads to autocorrelation. Secondly, most of the financial innovation variables have small time periods. For example, as at the end of the study period, agency banking innovation has been in use in Kenya for only 3 years (2010 - 2013), mobile money for 7 years (2007 - 2013), and internet banking data has been available for a five-year period (2009 - 2013). Thirdly, the nature of accounting data used to generate accounting returns (ROE and $\mathrm{ROA}$ ) is prone to measurement errors due to variations in accounting policies across firms with regard to the treatment of a number of items in financial statements. Lastly, the panel data set time dimension is short $(t=10)$ and has a larger country (firm) dimension $(n=42)$. In this article, we apply the Systems GMM estimator of Blundell and Bond (1998), which assumes that the first differences of the instruments are not correlated with the fixed effects parameters which then increase the number of probable instruments which would be used in estimating the model parameters (Arellano \& Bover 1995; Blundell \& Bond 1998; Fowowe \& Babatunde 2013).

\section{Control variables}

The purpose of the control variables is to control any other factors which may affect the dependent variables other than the main independent variables, which enhances the robustness of the final results. The industrial/organisation theory states that firm performance variations can be explained by the structural features of the sectors in the industry in which the firm operates (Kamasak 2011). This implies a direct relationship between industry performance 
and firm performance. The banking industry ROE and ROA, therefore, are included in the model as control variables. Since the structure of the industry affects firm performance, the peer grouping of the Kenyan banks is also factored in the model as a control variable. The banks are grouped into three peer groups, namely, large, medium and small. We further control past firm and industry financial performance by including the lag of industry-adjusted ROE for each firm, while past industry performance is represented by the lag of industry ROE.

According to McGahan and Porter (2003), firm-driven performance persists at a slower rate compared to industrydriven factors. In their earlier work, McGahan and Porter (1999) find $76.6 \%-81.8 \%$ persistence of the industry-driven performance compared to $47.9 \%-65.5 \%$ persistence in firmspecific factors. The implication of these findings is that past firm and industry performance may affect present or future performance, but the past industry performance may have a bigger effect. Past firm and industry performance are included in the model as control variables.

A number of studies observe that foreign-owned firms perform better than locally owned firms and, therefore, foreign ownership has a positive impact on firm performance (Aydin, Sayim \& Yalama 2007). These findings are consistent with Goethals and Ooghe (1997), who find that foreignowned firms perform better than the locally owned Belgian firms. In view of these and other related findings, it is expected that the ownership of the firms is likely to influence the results of this study. Ownership of the firms is included in the model as ownership dummies, where ' 1 ' represents locally owned firms and ' 0 ' represents foreign-owned firms.

Of the 42 commercial banks studied, 10 are listed on the Nairobi Securities Exchange. In effect, due to the possibility that the listing may influence the results, a listing dummy is included in the regression with a listing dummy of ' 1 ' for listed banks, and ' 0 ' otherwise. Additionally, the performance of the economy where firms operate, affects their financial performance (Dollar, Hallward-Driemeier \& Taye 2005). As the economy grows, the economic environment wherein the firms operate becomes more conducive. In effect, bank loans uptake increases due to increased economic activities, coupled with reduced default on loans. To control the effect of economic performance on bank performance, GDP growth rates are used as control variables in the regression model.

Lastly, the context of an organisation or a firm to a large extent determines adoption and usage of innovations by the firm. The Technological-Organisational-Environmental literature suggests that the organisational context, such as the scope, firm size and the structure of management, has implications on financial innovation (Oliveira \& Martins 2011). A number of studies have attempted to link firm size to innovation adoption and usage. For example, Rogers (1995) argues that firm size is a proxy for a number of dimensions which collectively lead to innovations namely aggregate resources, technical expertise of employees and slack resources. Firm size is represented by the log of total assets.

\section{Results}

\section{Summary statistics}

Table 2 presents the summary statistics for all the variables used in the study. The observations range between 397 and 420 , indicating that the panel is unbalanced. Due to $\log$ transformations and scaling down of the variables to industry values, the standard deviations have been reduced. The table also shows that there are years with missing values, as discussed earlier. The missing values largely relate to the four financial innovations, since the innovations were introduced at different years over the study period. The industryadjusted ROE and ROA have been used to mitigate the effect of outliers, consistent with Kayanga's (2008) approach. Table 3 reports the correlation matrix for all the variables used in the analysis. The correlations among the independent variables are not high enough to suggest that there may be a problem of multicollinearity. As such, the variables can be included in our regressions.

\section{Empirical results}

This section discusses the regression results presented in Table 4 . The model tests the relationship between financial innovations and financial performance for Kenyan commercial banks. Financial performance has been measured by industryadjusted ROE and industry-adjusted ROA. The system GMM used for the study is an instrumental variable estimation technique. Specifically, it generates some internal instrument for explanatory variables, which helps to deal with the time invariant effect due to the panel structure of our data, as well as the problem of weak exogeneity. Thus, except for the dummy variable, all the other explanatory variables have been instrumented by their first lag. However, we differentiate between explanatory variables in which not only their present value but also their past value affects firm performance. To this variable, we include their first lag (which in the estimation

TABLE 2: Summary statistics for all the variables used in the study.

\begin{tabular}{llcccc}
\hline Variable & OBS & Mean & SD & Min & Max \\
\hline IndAdjROA & 397 & -0.80 & 2.65 & -18.88 & 6.45 \\
IndAdjROE & 395 & -4.08 & 7.10 & -49.95 & 9.26 \\
Lnmbtn & 420 & 16.48 & 10.88 & 0.00 & 25.01 \\
ATM & 420 & 0.03 & 0.11 & 0.00 & 1.12 \\
IB & 420 & 0.01 & 0.06 & 0.00 & 0.50 \\
AB & 420 & 0.01 & 0.05 & 0.00 & 0.40 \\
IndROA & 420 & 3.30 & 1.10 & 2.00 & 5.00 \\
IndROE & 420 & 27.30 & 2.45 & 23.00 & 31.00 \\
LNTA & 397 & 23.38 & 1.34 & 20.65 & 26.50 \\
LISTING & 420 & 0.24 & 0.43 & 0.00 & 1.00 \\
OWS & 420 & 0.67 & 0.47 & 0.00 & 1.00 \\
GDP & 420 & 4.78 & 1.58 & 1.50 & 7.00 \\
PG & 420 & 2.38 & 0.72 & 1.00 & 3.00 \\
\hline
\end{tabular}

Mean, average; SD, standard deviation; Min, minimum; Max, maximum; IndAdjROA, industryadjusted return on assets; IndAdjROE, industry-adjusted return on equity; Lnmbtn, The logarithm of number of mobile banking transactions; ATM, automated teller machine; IB, Internet banking; AB, Agency banking; IndROA industry return on assets; IndROE, industry return on equity; IndROA industry return on assets; IndROE, industry return on equity; LNTA, return on equity; IndROA industry return on assets; IndROE, industry return on equity; LNTA,
The logarithm of total assets for firm $i$ at time $t$; OWS, ownership; GDP, gross domestic product; PG, peer group. 
TABLE 3: Correlational matrix for all variables used.

\begin{tabular}{|c|c|c|c|c|c|c|c|c|c|c|c|c|c|}
\hline Variable & IndAdjROA & IndAdjROE & Lnmbtn & ATM & IB & $A B$ & IndROA & IndROE & LNTA & LISTING & OWS & GDP & PG \\
\hline IndAdjROA & 1.00 & - & - & - & - & - & - & - & - & - & - & - & - \\
\hline IndAdjROE & 0.83 & 1.00 & - & - & - & - & - & - & - & - & - & - & - \\
\hline Lnmbtn & 0.15 & 0.11 & 1.00 & - & - & - & - & - & - & - & - & - & - \\
\hline ATM & 0.13 & 0.17 & -0.09 & 1.00 & - & - & - & - & - & - & - & - & - \\
\hline IB & 0.25 & 0.18 & 0.13 & 0.31 & 1.00 & - & - & - & - & - & - & - & - \\
\hline$A B$ & 0.18 & 0.14 & 0.12 & 0.31 & 0.58 & 1.00 & - & - & - & - & - & - & - \\
\hline IndROA & 0.17 & 0.10 & 0.82 & -0.07 & 0.14 & 0.20 & 1.00 & - & - & - & - & - & - \\
\hline IndROE & 0.18 & 0.14 & 0.64 & -0.06 & 0.13 & 0.18 & 0.75 & 1.00 & - & - & - & - & - \\
\hline LNTA & 0.49 & 0.52 & 0.31 & 0.42 & 0.37 & 0.32 & 0.35 & 0.29 & 1.00 & - & - & - & - \\
\hline LISTING & 0.29 & 0.38 & -0.03 & 0.48 & 0.34 & 0.26 & -0.02 & -0.01 & 0.71 & 1.00 & - & - & - \\
\hline ows & 0.03 & -0.03 & -0.03 & 0.08 & 0.12 & 0.10 & -0.02 & -0.01 & -0.14 & 0.02 & 1.00 & - & - \\
\hline GDP & 0.06 & 0.06 & -0.40 & 0.04 & -0.03 & -0.02 & -0.14 & 0.09 & -0.08 & 0.02 & 0.03 & 1.00 & - \\
\hline PG & -0.37 & -0.46 & 0.03 & -0.52 & -0.39 & -0.28 & 0.03 & 0.02 & -0.82 & -0.76 & 0.14 & -0.02 & 1.00 \\
\hline
\end{tabular}

IndAdjROA, industry-adjusted return on assets; IndAdjROE, industry-adjusted return on equity; Lnmbtn, The logarithm of number of mobile banking transactions; IB, Internet banking; AB, Agency banking; IndROA industry return on assets; IndROE, industry return on equity; ATM, automated teller machine; LNTA, The logarithm of total assets for firm $i$ at time $t$; OWS, ownership; GDP, gross banking; IndROA industry return on
domestic product; PG, Peer group.

TABLE 4: Regression results for financial innovation and firm financial performance.

\begin{tabular}{|c|c|c|c|c|}
\hline \multirow[t]{2}{*}{ Variable } & \multicolumn{2}{|l|}{1} & \multicolumn{2}{|l|}{2} \\
\hline & IndAdjROE & SE & IndAdjROA & SE \\
\hline L.IndAdjROE & $0.15^{* * *}$ & 0.01 & - & - \\
\hline IndROE & -0.06 & 0.04 & - & - \\
\hline ows & $2.53^{* *}$ & 1.11 & $1.05^{* * *}$ & 0.33 \\
\hline L.IndROE & $-0.24^{* * *}$ & 0.05 & - & - \\
\hline IB & 4.09 & 10.58 & 2.84 & 2.52 \\
\hline L.IB & -9.91 & 15.53 & - & - \\
\hline LNTA & 1.68 & 1.79 & $0.57^{* * *}$ & 0.07 \\
\hline L.LNTA & -1.08 & 1.72 & - & - \\
\hline ATM & $31.79^{* *}$ & 12.44 & 1.74 & 2.77 \\
\hline$A B$ & $18.72^{* *}$ & 7.75 & 0.46 & 0.98 \\
\hline Lnmbtn & $0.06^{* * *}$ & 0.02 & $0.03^{* * *}$ & 0.00256 \\
\hline GDP & $0.34^{* * *}$ & 0.06 & $0.169^{* * *}$ & 0.0156 \\
\hline Large & 0.84 & 0.51 & - & - \\
\hline Medium & 0.49 & 0.35 & - & - \\
\hline L.IndAdjROA & - & - & $0.254^{* * *}$ & 0.00788 \\
\hline IndROA & - & - & $-0.164^{* * *}$ & 0.0451 \\
\hline _Cons & $-15.11^{* *}$ & 6.58 & $-15.42^{* * *}$ & 1.733 \\
\hline$N$ & 308 & - & 355 & - \\
\hline $\operatorname{Ar}(2)$ test & $Z=0.31726$ & - & $Z=-1.6547$ & - \\
\hline Sargan test & $\operatorname{chi} 2(130)=28.31586$ & - & $\operatorname{chi} 2(175)=35.76437$ & - \\
\hline Wald & $\operatorname{chi} 2(15)=1685.43^{* * *}$ & - & $\operatorname{chi} 2(9)=3067.28 * * *$ & - \\
\hline
\end{tabular}

Note: This table reports the regression results for financial innovation and firm performance. The variables are defined in Table 1.

$\mathrm{SE}$, Standard error; IndAdjROE Industry-adjusted return on equity; IndAdjROA Industry adjusted return on assists; OWS, ownership; L.IndROE, Lagged value of the average value of the industry return on equity at time $t$; IB, Internet banking; L.IB, lagged value of interne banking; LNTA, The logarithm of total assets for firm $i$ at time $t$; L.LNTA, Lagged value of the logarithm of total assets for firm $i$ at time $t$; ATM, automated teller machine; AB, Agency banking; Lnmbtn, The logarithm of number of mobile banking transactions for firm $i$ at time $t$; GDP, gross domestic product; L.IndAdjROA, IndAdjROE, industry-adjusted return on equity; IndROA, Average value of the industry return on assets; _Cons, Constant $N$, number; $\operatorname{Ar}(2)$ test, Arellano-Bond test for zero autocorrelation in first-difference errors; Sargan test, Sargan test of overidentifying restrictions; Wald, Wald test for joint significance of the independent variables.

$* * *, * *, *$, indicate statistical significance at the $1 \%, 5 \%$ and $10 \%$ levels, respectively.

procedure has been instrumented by their second lag) and level (which has also been instrumented by their first lag). Hence, even though, variables such as AB, LNMTBN and ATMs are reported as level, in general, system GMM makes use of their first lags. This explains the reason why some variables are lagged, while others are not.

Each of the performance measures has been included as the dependent variable in the model. In each case, both the Arellano-Bond test for zero autocorrelation in first-difference errors (AR 2 test) and the Sargan test of overidentifying restrictions are carried out. The two tests confirm no autocorrelation and that overidentifying restrictions are valid in the regression models. Additionally, the Wald test for joint significance of the independent variables confirms that the independent variables are jointly significant at the $1 \%$ level of significance in driving firm financial performance. Therefore, the model is appropriate for testing the relationship between financial innovation and firm performance.

Although the results largely provide evidence that financial innovations have a significant positive impact on banks' financial performance, we observe varying results depending on the performance measure used. With regard to industryadjusted ROE, the coefficients are statistically significant at the 5\% level of significance for both ATMs and agency banking. The results further indicate that mobile banking significantly affects firm performance at the $1 \%$ level of significance. These results are also economically significant in view of the size of the effect that the independent variables have on the dependent variable (firm performance). The size of the effect that the independent variables have on firm performance is measured by the size of the coefficients of the independent variables. According to the results in Table 4, the coefficients are significantly above zero, at 31.79, 18.72 and 0.064 for ATMs, agency banking and mobile banking proxies, respectively. Importantly, the coefficients have positive signs as expected, providing evidence that the financial innovations significantly and positively drive banking performance, as measured by industry-adjusted ROE. Although the effect of internet banking on firm performance is not statistically significant at all conventional levels, the effect is positive as evidenced by a positive coefficient of 4.09 .

These results confirm the dominance of mobile banking (non-bank-led model) over the other two branchless banking models. This can be explained by a number of observations made in the study. Firstly, the dominance of mobile payments' customer numbers over the other electronic payments is an indication of the popularity of mobile banking in Kenya. Although the contribution of agency banking to firm performance is significant at the $5 \%$ level 
of significance, agency banking was in operation for only 3 years over the 10-year study period. The implication is that the impact of agency banking is likely to be felt more in the future, considering the fact that the impact of financial innovation on firm performance is time lagged. In addition, agency banking has been adopted by only 13 out of 42 commercial banks, thus the innovation is yet to be felt more widely.

The contribution of ATMs to firm performance is statistically significant at the $5 \%$ level. This is in spite of the fact that a number of banks (including multinationals) in Kenya have not installed their own ATMs. These banks have linked their customers to a shared platform referred to as Kenswitch ${ }^{3}$. Moreover, Visa and Mastercard branded ATMs enable the sharing of the ATM network globally, implying that individual firms sharing the ATM platforms may not necessarily have the incentive to install many ATMs in view of the huge installation cost per ATM machine. Nevertheless, ATM usage has a significant impact on firm financial performance. The results in Table 4 show that internet banking positively affects firm performance, but the contribution is insignificant. A firm's past performance has a statistically significant positive impact at the $1 \%$ level of significance, while the industry's impact on firm financial performance is negative and insignificant when both industry $\mathrm{ROE}$ and ROA are used. However, when only industry ROA is used, the impact of the industry on firm performance is negative, but statistically significant at all conventional levels. It appears that industry performance is generally not a major driver of any individual bank's firm performance in Kenya.

When industry-adjusted ROA is used, size significantly and positively affects firm performance, while the coefficient on size becomes insignificant when industry-adjusted ROE is used. This could be explained by the fact that total assets, used as the proxy for firm size, comprise the resources controlled by the firm, which have been found to drive firm performance. The impact of firm size on firm performance buttresses the resource-based view which holds that performance variation among firms is mainly dependent on the resources which individual firms control (Galbreath \& Galvin 2008). However, these findings are not consistent with the industrial and/or organisation economic theory, which holds that firm performance variations can be explained by the structural features of the sectors in the industry wherein the firm operates (Kamasak 2011). The ownership structure of the banks has been used as a control variable in the regression. The results show that ownership structure has a statistically significant positive impact on firm performance. The size of the coefficient on the ownership variable is economically significant (at 2.52) and is positive as expected. This shows that locally owned banks are the leaders in the usage of financial innovations. As observed in the review of the banking sector performance, locally owned banks (three commercial banks) account for more than $90 \%$ of agency

3.Kenswitch is a shared financial switch comprising a consortium of over 20 Kenyan commercial banks, established so as to create a common switch and ATM network commercial banks, established so as to create a common switch and ATM
linking a number of small- and medium-sized banks in Kenya (LTS 2015). banking in Kenya. Lastly, this study finds a significant positive relationship between performance of the economy, as measured by GDP growth, and firm financial performance. Secondly, the size of the coefficient is big (at 0.34) and positive as expected. The implication of this finding is that the economic environment where commercial banks operate is critical in driving their financial performance. This is because when the economy is performing well, the uptake of development loans increases and default rates on such loans fall with positive implications on profitability.

We contend that ROA and ROE ordinarily measure different types of performance, and the interpretation of the results from our analysis needs to take this fact into consideration. ROA shows how a given bank uses its assets to generate revenue. Our results, therefore, suggest that over the duration of our study, ATMs, agency banking and internet banking do not significantly enable banks to generate revenue. This needs to be seen in the banking sector context. In the banking sector, ATMs and internet banking generate revenue if bank customers use the ATM and the internet to either deposit or withdraw cash as opposed to just checking account balances. Considering that agency banking has been in place for a very short time ( 3 years), perhaps in the long term these results will change. On the other hand, ROE shows profitability for the shareholders. It is the shareholders' view of how much they are getting from the profits made by the bank. We, therefore, provide evidence that financial innovations in the form of branchless banking models produce good results for the shareholders, implying that shareholders are the primary beneficiaries of financial innovations used by commercial banks. Overall, the study results presented in Table 4 provide evidence that mobile banking, ATMs and agency banking significantly explain the variation in firm financial performance in Kenya.

\section{Conclusions and recommendations for future research}

The empirical literature review in this article covers financial innovations, firm performance and Kenya's banking sector over the study period. Empirical studies on financial innovations and firm financial performance provide evidence of the link between the two. Nevertheless, most of the previous studies have concentrated on financial innovations in the form of financial products in developed countries. Although there are multiple meanings of 'firm performance', as well as diverse ways in which performance construct is operationalised in the literature, the focus of this study is on bank financial performance, as measured by the industry-adjusted ROE and ROA. The results show that financial innovations significantly contribute to bank financial performance, and that firm-specific factors are more important in determining the firm's current financial performance than are industry factors.

Management efforts at driving financial innovation should be consistent with the recent global trends. For example, a study of 246 CEOs from PricewaterhouseCoopers (PWC) 
Global CEO panel, comprising multinational companies across all sectors, company sizes from developed and emerging economies, makes important findings (PWC 2013:3). According to the study '... CEOs are now taking personal responsibility for directing and inspiring innovation as it becomes an ever more vital element of business survival and success ...' The implication of the PWC research and the results from this article is that management should recognise that innovation in general and financial innovation in particular, generate financial value and contribute to the success of the firm. Moreover, financial innovation is seen as encouraging banks to take on more risks, providing valuable credit as well as firms' risk diversification services (Beck et al. 2016). We recommend that future studies seek to establish whether financial innovation has a stronger relationship with past or future performance. Secondly, we suggest that future studies focus on obtaining ATM transaction data (if possible) to be able carry out a more in-depth study on the impact of ATMs on bank performance. Lastly, we suggest that future studies focus on the link between firm performance, financial innovation and the possibility of reverse causality between the two variables.

\section{Acknowledgements}

This work benefited from African Economic Research Consortium funding (AERC PhD Fellowship 2015).

\section{Competing interests}

The authors declare that they have no financial or personal relationships that may have inappropriately influenced them in writing this article.

\section{Authors' contributions}

M.M.M. wrote this article as a product of his PhD with C.C. as supervisor for the project.

\section{References}

Aduda, J. \& Kingoo, N., 2012, 'The relationship between electronic banking and financial performance among commercial banks in Kenya', Journal of Finance and Investment Analysis 1(3), 99-118.

Al-Ansari, Y., Pervan, S. \& Xu, J., 2013, 'Innovation and business performance of SMEs: the case of Dubai', Education, Business and Society: Contemporary Middle Eastern Issues 6(3/4), 162-180. https://doi.org/10.1108/EBS-04-2013-0012

Arellano, M. \& Bond, S., 1991, 'Some tests of specification for panel data: Monte Carlo evidence and an application to employment equations', The Review of Economic Studies 58(2), 277-297. https://doi.org/10.2307/2297968

Arellano, M. \& Bover, O., 1995, 'Another look at the instrumental variable estimation of error-components models', Journal of Econometrics 68(1), 29-51. https://doi. org/10.1016/0304-4076(94)01642-D

Artz, K.W., Norman, P.M., Hatfield, D.E. \& Cardinal, L.B., 2010, 'A longitudinal study of the impact of R\&D, patents, and product innovation on firm performance', Journa of Product Innovation Management 27(5), 725-740. https://doi.org/10.1111/ j.1540-5885.2010.00747.x

Aydin, N., Sayim, M. \& Yalama, A., 2007, 'Foreign ownership and firm performance: Evidence from Turkey', International Research Journal of Finance and Economics $11,103-111$.

Beck, T., Chen, T., Lin, C., \& Song, F.M., 2016, 'Financial innovation: The bright and the dark sides', Journal of Banking \& Finance 72, 28-51.

Blundell, R. \& Bond, S., 1998, 'Initial conditions and moment restrictions in dynamic panel data models', Journal of Econometrics 87(1), 115-143. https://doi. org/10.1016/S0304-4076(98)00009-8

Bowen, F.E., Rostami, M. \& Steel, P., 2010, 'Timing is everything: A meta-analysis of the relationships between organizational performance and innovation', Journa of Business Research 63(11), 1179-1185. https://doi.org/10.1016/j.jbusres.2009. 10.014
Cainelli, G., Evangelista, R. \& Savona, M., 2006, 'Innovation and economic performance in services: A firm-level analysis', Cambridge Journal of Economics 30(3), 435-458. in services: A firm-level analysis, Cam
httoi.org/10.1093/cje/bei067

CBK, 2010, Bank supervision annual report, Central Bank of Kenya, Nairobi.

CBK, 2013, Bank supervision annual report, Central Bank of Kenya, Nairobi.

CBK, 2015, 'Payment Systems Statistics', Mobile Payments, viewed 26 July 2015, from https://www.centralbank.go.ke/index.php/nps-modernization/mobile-payments

Cracknell, D., 2012, Policy innovations to improve access to financial services in developing countries: Learning from case studies in Kenya, viewed 06 May 2012 developing countries: Learning from case studies in Kenya, viewed $06 \mathrm{M}$
from http://www.cgdev.org/doc/LRS_case_studies/Cracknell_Kenya.pdf

Demirgüç-Kunt, A. \& Klapper, L.F., 2012, Measuring financial inclusion: The global findex database, viewed 12 August 2015, from http://elibrary.worldbank.org/doi/ abs/10.1596/18139450-6025

Dess, G.G. \& Robinson, R.B., 1984, 'Measuring organizational performance in the absence of objective measures: The case of the privately-held firm and conglomerate business unit', Strategic Management Journal 5(3), 265-273. https://doi.org/10.1002/smj.4250050306

Deyoung, R., Lang, W.W. \& Nolle, D.L., 2007, 'How the Internet affects output and performance at community banks', Journal of Banking \& Finance 31(4), 10331060. https://doi.org/10.1016/j.jbankfin.2006.10.003

Dollar, D., Hallward-Driemeier, M. \& Taye, M., 2005, 'Investment climate and firm performance in developing economies', Economic Development and Cultura Change 54(1), 1-31. https://doi.org/10.1086/431262

EIU, 2012, Global microscope on the Micro finance business environment 2012, viewed 14 April 2014, from http://www.eiu.com/public/topical_report.aspx? campaignid=microscope 2012

EIU, 2015, Global Microscope 2015 The enabling environment for financial inclusion, viewed 15 October 2016, from http://www.eiu.com/public/topical_report.aspx?c ampaignid=MicroscopeDec 2015

Fowowe, B. \& Babatunde, A., 2013, 'The effect of financial development on poverty and inequality in African countries', The Manchester School 81(4), 562-585. https://doi.org/10.1111/j.1467-9957.2012.02302.x

Frambach, R.T. \& Schillewaert, N., 2002, 'Organizational innovation adoption: A multilevel framework of determinants and opportunities for future research', Journal of Business Research 55(2), 163-176. https://doi.org/10.1016/S0148-2963(00) of Business

Frame, W.S. \& White, L.J., 2004, 'Empirical studies of financial innovation: Lots of talk, little action?', Journal of Economic Literature 42(1), 116-144. https://doi.org/ 10.1257/.42.1.116

Frame, W.S. \& White, L.J. (eds.), 2014, Technological change, financial innovation, and diffusion in banking: The Oxford handbook of banking, Oxford University Press, Oxford

Galbreath, J. \& Galvin, P., 2008, 'Firm factors, industry structure and performance variation: New empirical evidence to a classic debate', Journal of Business Research 61(2), 109-117. https://doi.org/10.1016/j.jbusres.2007.06.009

German-Soto, V. \& Flores, L.G. 2015. 'Contribution of education and innovation to productivity among Mexican regions: A dynamic panel data analysis', Theoretical Economics Letters 5, 44-55.

Goethals, J. \& Ooghe, H., 1997, 'The performance of foreign and national take-overs in Belgium', European Business Review 97(1), 24-37. https://doi.org/10.1108/ 09555349710156037

Gopalakrishnan, S., 2000, 'Unraveling the links between dimensions of innovation and organizational performance', The Journal of High Technology Management Research 11(1), 137-153. https://doi.org/10.1016/S1047-8310(00)00024-9

Griliches, Z., 1967, 'Distributed lags: A survey', Econometrica 36(1), 16-49. https://doi. org/10.2307/1909382

Gujarati, D.N., 2003, Basic econometrics, 4th edn., McGraw-Hill, New York.

Hernando, I. \& Nieto, M.J., 2007, 'Is the Internet delivery channel changing banks performance? The case of Spanish banks', Journal of Banking \& Finance 31(4) 1083-1099. https://doi.org/10.1016/j.jbankfin.2006.10.011

Hughes, N. \& Lonie, S., 2007, 'M-PESA: Mobile money for the "unbanked" turning cell phones into 24 hour tellers in Kenya', Innovations 2, 1-2.

Ingenico, 2012, Electronic payment architecture and trends in Europe, viewed 07 June 2014, from http://www.ingenico.com.br/zee_uploads/all/all/gallery_gallery/3760/ electronic-payment-and-trends-in-europe.pd $\bar{f}$

Jepkorir, S. 2010. Challenges of implementing financial innovations by commercial banks in Kenya, Masters of Business Administration, University of Nairobi.

Jiménez-Jiménez, D. \& Sanz-Valle, R., 2011, 'Innovation, organizational learning and performance', Journal of Business Research 64(4), 408-417. https://doi.org/ 10.1016/j.jbusres.2010.09.010

Kamasak, R., 2011, 'Firm-specific versus industry structure factors in explaining performance variation: Empirical evidence from Turkey', Management Research Review 34(10), 1125-1146. https://doi.org/10.1108/01409171111171519

Katz, M.L. \& Shapiro, C., 1986, 'Technology adoption in the presence of network externalities', The Journal of Political Economy 94(4), 822-841. https://doi.org/ $10.1086 / 261409$

Kayanga, A.M., 2008, Essays in corporate governance: Issues and evidence from equity carve-outs, viewed 11 February 2014, from http://scholarworks.uno.edu/cgi/ viewcontent. cgi?article $=1872 \&$ context $=$ td

Kimenyi, M.S. \& Kibe, J., 2014, Africa's powerhouse, viewed 10 November 2015, from http://www.brookings.edu/research/opinions/2013/12/30-kenya-economykimenyi 
Kirby, J., 2005, 'Toward a theory of high performance', Harvard Business Review 83(7), 30-39.

Koyck, L.M., 1954, Distributed lags and investment analysis, North Holland Publishing Company, Amsterdam.

Laeven, L., Levine, R. \& Michalopoulos, S., 2015, 'Financial innovation and endogenous growth', Journal of Financial Intermediation 24, 1-24. https://doi.org/10.1016/j. jfi.2014.04.001

Laforet, S., 2013, 'Organizational innovation outcomes in SMEs: Effects of age, size, and sector', Journal of World Business 48(4), 490-502. https://doi.org/10.1016/j. jwb.2012.09.005

Laforet, S. \& Tann, J., 2006, 'Innovative characteristics of small manufacturing firms', Journal of Small Business and Enterprise Development 13(3), 363-380. https:// doi.org/10.1108/14626000610680253

Lerner, J., 2006, 'The new new financial thing: The origins of financial innovations', Journal of Financial Economics 79(2), 223-255.

Lopez, L.E. \& Roberts, E.B., 2002, 'First-mover advantages in regimes of weak appropriability: The case of financial services innovations', Journal of Business Research 55(12), 997-1005. https://doi.org/10.1016/S0148-2963(01)00200-4

LTS, 2015, Kenswitch, viewed 11 March 2016, from http://www.Ixsinternational.com/ kenswitch.php

Makini, S. O. 2010. The relationship between financial innovation and financia performance of commercial banks in Kenya. Master of Business Administration, University of Nairobi.

Mcgahan, A.M. \& Porter, M.E., 1999, 'The persistence of shocks to profitability' Review of Economics and Statistics 81(1), 143-153. https://doi.org/10.1162/ 003465399767923890
Mcgahan, A.M. \& Porter, M.E., 2003, 'The emergence and sustainability of abnormal profits', Strategic Organization 1(1), 79-108. https://doi.org/10.1177/147612 7003001001219

Muthinja, M.M. \& Chipeta, C., 2017, 'What drives financial innovations in Kenya's Commercial Banks? An empirical study on firm and macro-level drivers of branchless banking', Journal of African Business [online] 1-24. https://doi.org/ 10.1080/15228916.2017.1405705

Mwando, S., 2013,. 'Contribution of agency banking on financial performance of commercial banks in Kenya', Journal of Economics and Sustainable Development 4(20), 26-34.

Oliveira, T. \& Martins, M.F., 2011, 'Literature review of information technology adoption models at firm level', The Electronic Journal Information Systems Evaluation 14(1), 110-121.

PWC, 2013, Unleashing the power of innovation, viewed 02 July 2015, from http:// www.pwc.com/gx/en/innovationsurvey/files/innovation_full_report.pdf

Rogers, E.M., 1995, Diffusion of innovations, 3rd edn., Free Press, New York.

Rosenbusch, N., Brinckmann, J. \& Bausch, A., 2011, 'Is innovation always beneficial? A meta-analysis of the relationship between innovation and performance in SMEs', Journal of Business Venturing 26(4), 441-457. https://doi.org/10.1016/j. jbusvent.2009.12.002

Shapiro, C., Varian, H.R. \& Becker, W.E., 1999, 'Information rules: A strategic guide to the network economy', Economic Education 30, 189-190.

Siedek, H., 2008, Extending Financial Services with Banking Agents, Brief, CGAP Washington, D.C.

Tufano, P., 2003, 'Financial innovation', Handbook of the Economics of Finance 1 307-335. https://doi.org/10.1016/S1574-0102(03)01010-0 